JPW (Jurnal Politik Walisongo) - Vol 1, No 1 (2019), 65--74

ISSN: 2503-3190 (p); 2503-3204 (e)

DOI: 10.21580/jpw.2019.1.1.2338

\title{
Kontestasi Pasangan Suami Istri dalam Pilkades
}

\author{
Puji Astuti, ${ }^{1}$ Sulistyowati, ${ }^{2}$ Lusia Astrika ${ }^{3}$ \\ 1,2,3Universitas Diponegoro, Semarang - Indonesia
}

\begin{abstract}
The Act Number 6 of 2014 cause of a great implication especially on the election of village chief. More over regarding on Ministerial Regulation Number 112 Year of 2014, article 23, which prohibit the single candidate opposing with the empty of ballot box. Thus, prohibition emerging of interesting phenomenon where is 17 couples of husband and wife being contestant on the village chief election in Demak Regency in the year of 2016. The aims of the reserch is to comprehend the husband's reason to choose his wife as associate candidate. Do thus fact be part of practicing of women subordination? How the influence of thus phenomenon to the village democracy itself? The research uses qualitative-descriptive method with depth interview as instrument in collecting data. The result show that there are two main husband's reason choose his wife as a competitor. Fisrt, by choosing his wife mean that there is no cost for compensation and no hard worry about conflict of interest in the coming day after election. Second, becoming his wife as a competitor mean that the winning opportunity is greater because patriarchy and Islamic tradition (were more joy in placing men as a leader) in Demak Regency. Then, the emerging of husband and wife as a candidate would decrease of democracy because there no rivalry as a soul of democracy. To improve of village chief election as a source of village democracy, it is best to correct the regulation which prohibit of the a single canditate by completing with require that the village chief election should be follow by at least two candidate who both of them have no relation as nuclear family.

Undang-Undang Nomor 6 Tahun 2014 berimplikasi besar pada pemilihan kepala desa. Terlebih lagi Peraturan Menteri Nomor 112 Tahun 2014, pasal 23, yang melarang calon tunggal yang menentang dengan kotak suara kosong. Dengan demikian muncul fenomena menarik, ada 17 pasangan suami-istri menjadi kontestan dalam pemilihan kepala desa di Kabupaten Demak pada tahun 2016. Tujuan penelitian ini memahami alasan suami untuk memilih istrinya sebagai calon rival. Apakah dengan demikian fakta menjadi bagian dari praktik subordinasi perempuan? Bagaimana pengaruh fenomena tersebut terhadap demokrasi desa itu sendiri? Penelitian ini menggunakan metode kualitatif-deskriptif dengan wawancara mendalam sebagai instrumen dalam mengumpulkan data. Hasilnya menunjukkan bahwa ada dua alasan utama suami memilih istrinya sebagai pesaing. Pertama, dengan memilih istrinya berarti bahwa tidak ada biaya untuk kompensasi dan tidak ada kekhawatiran tentang konflik kepentingan di hari berikutnya setelah pemilihan Kedua, menjadi istrinya sebagai pesaing berarti peluang menang lebih besar karena patriarki dan tradisi Islam (lebih suka menempatkan pria sebagai pemimpin) di Kabupaten Demak. Kemudian, kemunculan suami-istri sebagai kandidat akan berkurang demokrasi karena tidak ada persaingan sebagai jiwa demokrasi. Untuk meningkatkan pemilihan kepala desa sebagai sumber demokrasi desa, yang terbaik adalah mengoreksi peraturan yang melarang kandidat tunggal dengan mensyaratkan bahwa pemilihan kepala desa harus diikuti oleh setidaknya dua kandidat yang keduanya tidak memiliki hubungan sebagai keluarga inti.
\end{abstract}

Keywords: chief of village election; empty of ballot box; patriarchy, women subordination

${ }_{1}^{1}$ Korespondensi: Puji Astuti (astutipuji4@yahoo.co.id), FISIP Universitas Diponegoro, Jl. Prof. Soedarto No.13, Tembalang, Semarang 50275 - Indonesia. 


\section{Pendahuluan}

Satu hal yang paling khas dari desa di Indonesia, khususnya di Jawa adalah adanya otonomi desa dengan keasliannya yang bahkan oleh pemerintah kolonial belanda diakui dan dihormati, termasuk dalam pemilihan kepala desa. Pemerintah kolonial belanda mengakui otonomi desa dengan memberikan hak kepada desa untuk mengatur penyelenggarakan pemerintahan dan rakyat berdasarkan pada adat istiadat dan kebudayaan yang berlaku di wilayah setempat. Pernyataan tersebut menunjukan bahwa sesungguhnya desa di Indonesia telah sejak lama secara empirik mempraktekan nilainilai demokrasi. Basis utama dalam pemilihan kepala desa adalah memilih pemimpin yang mampu mengadaptasi dengan nilai-nilai yang ada di masyarakat (kepemimpinan kultural). Namun sejak masa kemerdekaan, desa mengalami banyak perubahan, terutama sejak berlakunya UU No 5 tahun 1979. Undang-undang No 5 tahun 1979 tentang desa secara perlahan tapi pasti telah merubah praktek otonomi desa yang sangat beragam digantikan oleh sistem penyelenggaraan pemerintahan desa yang lebih sentralistik dan mengedepankan aspek administratif, termasuk dalam pemilihan kepala desa. Bahkan intervensi rezim orde baru terhadap proses Pilkades (Pemilihan Kepala Desa) sejak lahirnya Undang-Undang No. 5 Tahun 1979 sangatlah kuat dengan tujuan menghasilkan pemimpin yang bisa menjadi kepanjangan tangan pemerintah.

Lahirnya Undang-Undang No. 6 Tahun 2014 tentang Pemerintahan Desa memberikan harapan besar atas kembalinya otonomi dan demokrasi desa. Namun, terdapat beberapa hal yang menarik yang akan mempengaruhi dinamika pemilihan kepala desa, terutama karena UU yang baru mengatur bahwa jabatan kepala desa dapat diemban untuk tiga kali masa jabatan secara berturut-turut. Kemudian dalam Peraturan Menteri Dalam Negeri Nomor 112 tahun 2014 mengatur bahwa Pilkades dilakukan secara serentak (pasal
2) dan calon dalam Pilkades sedikitnya 2 orang calon dan sebanyak-banyaknya 5 orang calon (Pasal 23). Peraturan tersebut menyiratkan bahwa dalam Pilkades tidak lagi diperbolehkan adanya calon tunggal melawan kotak kosong. Pada prakteknya larangan untuk melawan kotak kosong ternyata memunculkan fenomena menarik dalam Pilkades serentak tahap pertama di Kabupaten Demak. Terdapat 17 pasangan suami istri yang maju sebagai kontestan dalam Pilkades. Majunya seorang istri sebagai calon pendamping yang bersaing dengan suaminya merupakan fenomena yang menarik untuk dikaji dalam ruang lingkup politik.

Berdasar pada fenomena tersebut maka kajian ini akan berfokus pada analisis fenomena pasangan suami istri dalam Pilkades dengan mengacu pada dua rumusan permasalahan. Pertama yakni mengapa calon kepala desa memilih istrinya sebagai calon pendamping dalam kontestasi Pilkades? Kedua yakni bagaimana dampak yang akan ditimbulkan dari fenomena tersebut terhadap demokrasi desa? Kajian atas fenomena pasangan suami istri dalam kontestasi Pilkades menjadi penting untuk dikaji karena jika ditinjau melalui perspektif gender fenomena tersebut bukan hanya strategi politik untuk memenuhi persyaratan administrasi dalam Pilkades, namun dapat dimaknai sebagai praktek subordinasi yang paling nyata dalam sebuah proses politik. Selain itu, kajian atas fenomena pasangan suami istri dalam kontestasi Pilkades jadi penting untuk dikaji karena dapat menjadi framework atas praktik manipulasi proses demokrasi, mengingat fenomena tersebut membawa kompetisi semu dalam proses kontestasi Pilkades, sesungguhnya tidak ada rivalitas yang merupakan roh dari proses demokrasi.

Penelitian ini bersifat deskriptif-kualitatif dengan tujuan memberikan gambaran secara komprehensif terkait analisis fenomena suami istri sebagai kontestan dalam Pilkades serentak di Kabupaten Demak tahun 2016. Wawancara mendalam atau indepth interview akan diguna- 
kan sebagai alat penggalian data utama dalam menggali informasi terkait faktor-faktor dan alasan yang melatarbelakangi munculnya fenomena pasangan suami istri dalam kontestasi Pilkada serentak di Demak tahun 2016. Pada konteks ini wawancara mendalam akan ditujukan kepada beberapa pasangan suami istri yang mencalonkan diri pada Pilkades serentak di Demak tahun 2016. Sedangkan wawancara mendalam yang ditujukan kepada perangkat masyarakat, penyelenggara Pilkades Demak tahun 2016 juga masyarakat dilakukan guna mendapat informasi yang komprehensif terkait dampak atas praktek pencalonan suami istri dalam Pilkades, khususnya dampak dalam pelaksanaan demokrasi desa. Semua data yang diperoleh kemudian akan diidentifikasi melalui koding untuk kemudian dianalisis secara induktif guna mendaptkan makna yang ada dalam fenomena pencalonan suami istri dalam Pilkades Demak tahun 2016.

\section{Pilkades dan Praktek Subordinasi Perempuan}

Desa dengan berbagai varian nama yang berbeda telah lama bertahan hidup dengan tradisi sebagai sumber otonominya. Realitas ini dapat dibuktikan dengan pengakuan dan penghormatan oleh pemerintah kolonial terhadap otonomi desa. Desa di Jawa sangat lekat dengan pepatah "desa mawa cara, negara mawa tata" yang maknanya yakni desa memiliki caranya sendiri dalam mengatur dan mengelola rakyat dan pemerintahanya yang berakar pada nilai-nilai dan tradisi lokal. Pengakuan pemerintah kolonial Belanda terhadap otonomi desa, termasuk di dalamnya adalah hak dalam memilih pemimpinnya. Sudah berabad-abad lamanya desa di Jawa memiliki tradisi memilih pemimpinnya secara langsung. Namun saat ini pelaksanaan Pilkades justru banyak diintervensi oleh berbagai regulasi baik pemerintah pusat maupun kabupaten yang mengubah tata cara pelaksanaan Pilkades dengan persyaratan-persyaratan administratif yang sangat dominan.

Masa jabatan kepala desa yang dapat dipegang selama tiga periode kepemimpinan secara berturut-turut sebagaimana diatur dalam UU No 6 tahun 2014 tentu akan berimplikasi besar terhadap dinamika Pilkades, terutama di desa-desa yang memiliki potensi kekuatan ekonomi. Namun yang tidak kalah menarik adalah larangan calon tunggal untuk dilawankan dengan kotak kosong sebagaimana diatur dalam pasal 23 Peraturan Menteri Dalam Negeri No 112 tahun 2014. Munculnya larangan tersebut tidak lepas dari pengalaman mahalnya ongkos politik Pilkades melawan kotak kosong yang menyebabkan Pilkades harus diulang beberapa kali jika kemenangan justru diperoleh kotak kosong. Pengulangan proses Pilkades tidak hanya berimplikasi pada mahalnya biaya Pilkades secara ekonomi, akan tetapi juga secara sosial, terutama karena munculnya konflik horisontal di kalangan pendukung calon dan pendukung kotak kosong. Namun larangan ini ternyata memunculkan fenomena baru yang cukup menarik yaitu munculnya pasangan suami istri sebagai kontestan dalam Pilkades.

Pada Pilkades serentak tahap pertama tahun 2016 di Kabupaten Demak muncul 17 pasangan suami istri yang maju bersama dalam Pilkades. Berdasar pada fakta tersebut muncul pertanyaan menarik untuk dikaji yakni terkait dengan alasan yang melatarbelakangi mengapa seorang suami memutuskan istrinya sebagai kompetitor dalam pencalonan dirinya dalam Pilkades. Dari hasil wawancara mendalam terhadap sumber informasi ternyata ada jawaban yang hampir seragam. Minimalisasi biaya pencalonan kepala desa menjadi alasan utama yang melatarbelakangi fenomena pasangan suami istri dalam kontestasi Pilkades. Biaya tersebut merujuk pada biaya administrasi pencalonan pun biaya proses kampanye. Selain itu pertimbangan lain yang turut mendasari yakni kompensasi yang harus 
diberikan kepada lawan (kompetitor lain dalam Pilkades) sebagai pengganti kotak kosong. Seperti yang disampaikan oleh Budi Utomo:

"Saya memutuskan memilih istri sebagai lawan karena setelah menunggu sampai mendekati batas akhir pendaftaran tidak ada calon yang lain. Dengan memilih isteri sendiri artinya juga saya tidak harus mengeluarkan uang untuk kompensasi. Ini berbeda kalau saya meminta orang lain untuk mendampingi pencalonan saya. Siapasih orang yang secara sukarela mau menjadi calon pura-pura? Tentu mereka akan meminta imbalan apakah uang, jabatan, ataupun imbalan lainnya". (Budi Utomo, Kepala Desa Jatirejo)

Berdasar pada pernyataan Budi dapat disimpulkan bahwa persoalan besaran biaya pencalonan dan kompensasi menjadi pertimbangan utama dalam pemilihan istri sebagai kompetitor dalam kontestasi Pilkades.

Pernyataan serupa juga disampaikan oleh Agus Sudiarto:

"Saya memutuskan memilih istri sebagai lawan dalam Pilkades karena aturan menetapkan bahwa pemilihan harus diikuti sedikitnya oleh dua calon. Faktanya sampai waktu pendaftaran hampir berakhir tidak ada calon lain yang mendaftar. Maka segera saya meminta kesediaan istri untuk maju sebagai calon pendamping. Alasanya di samping terkait dengan masalah kompensasi, maka sederhana saja yaitu kalau saya tidak beruntung dan kalah, maka kemenangan masih ada pada keluarga kami. Artinya uang yang sudah kami keluarkan tidak sia-sia dan juga prestise keluarga tidak hancur". (Agus Sudiarto, Kepala Desa Karanganyar)

Pernyataan Agus Sudiarto menyiratkan bahwa kontestasi Pilkades bukan hanya persoalan kuasa saja, namun juga terkait persoalan gengsi sosial (social prestige). Terpilihnya kontestan Pilkades akan meningkatkan gengsi sosial yang dimilikinya pun keluarga besarnya, namun sebaliknya jika kontestan Pilkades kalah maka tidak hanya akan berdampak pada ketidakpemilikan kuasa tapi juga turut menurunkan gengsi sosialnya.

Persoalan lain justru disampaikan oleh Suyudi yang lebih menitikberatkan pada resiko yang melekat pada pencalonan Pilkades jika harus menunjuk atau bekerjasama dengan pihak lain sebagai kompetitor (pengganti kotak kosong).

"Jika saya tidak memilih istri dan memilih orang lain misalnya teman atau saudara, maka saya khawatir di belakang hari terjadi hal-hal yang tidak diinginkan. Bisa saja di awal kita membuat beberapa kesepakatan, tapi siapa yang bisa menjamin bahwa yang bersangkutan akan memegang teguh kesepakatan dan tidak menusuk kita dari belakang di kemudian hari. Jadi sebelum itu terjadi saya mengantisipasinya dengan memilih istri. Namanya istri itu kan wajar patuh pada suami sehingga tidak bisa menolak, meskipun awalnya mungkin juga ragu-ragu". (Suyudi, Kepala Desa Jatirogo)

Pernyataan Suyudi menjadi representasi atas resiko politik yang selalu melekat pada setiap proses demokrasi politik. Oleh karena itu pemilihan istri sebagai kompetitor menjadi satu strategi untuk meminimalisasi resiko dalam proses pencalonannya dalam Pilkades.

Perspektif lain juga dimiliki oleh Sutejo yang memilih isri sebagai kompetitor dalam pencalonan Pilkades merupakan strategi politik yang digunakannya untuk merespon situasi dan kondisi pribadi yang dimilikinya seperti persoalan batasan umur. Pernyataan tersebut disampaikan oleh Sutejo:

"Saya memilih istri jujur saja ini strategi politik saya yang ingin mengambil kesempatan sebagai kepala desa untuk ke tiga kalinya karena Undang-undang 2014 memungkinkan untuk itu. Dulu saya juga kepala desa selama dua periode, kemudian saya kembali melanjutkan karier sebagai 
PNS. Istri saya sebenarnya juga mantan kepala desa selama dua periode setelah saya dua kali menjabat. Seandainya saya tidak mencalonkan dan isteri saya maju lagi saya jamin pasti menang karena sesungguhnya isteri saya lebih banyak berkiprah di masyarakat. Tapi ini kesempatan saya terakhir dari persyaratan usia sehingga saya minta istri untuk mengalah. Tentu dalam proses pencalonan ini saya dan tim sukses (gapit) mengarahkan warga agar suaranya diberikan kepada saya, bahkan istri saya membantu ikut mengkampanyekan agar masyarakat tidak memilih dirinya tetapi memilih saya". (Sutejo, Kepala Desa Tlogoweru)

Beberapa pernyataan tersebut menyiratkan bagaimana dominasi laki-laki (suami) dalam pengambilan keputusan yang terepresentasi melalui permintaan dan perintah suami kepada istrinya untuk menjadi kompetitor 'gadungan' (pura-pura) dalam kontestasi Pilkades dengan berbagai alasan yang menyertainya. Jika ditelusuri lebih jauh praktek tersebut tidak lepas dari budaya patriarki yang masih sangat kental di masyarakat. Budaya patriarki sendiri merupakan konsep yang menitikberatkan pada kekuasaan ayah atau dapat menggambarkan tipe khusus keluarga yang didominasi oleh laki-laki. Saat ini patriarki secara umum lebih banyak dikaitkan dengan dominasi laki-laki, hubungan kekuasaan dimana laki-laki mendominasi perempuan, dan ciri sebuah sistem dimana perempuan tersubordinasi dengan berbagai bentuknya (Bhasin 2006). Patriarki sendiri menarik perhatian banyak ilmuwan yang melihat patriarki dari berbagai perspektif. Walby misalnya mendefinisikan patriarki sebagai suatu sistem struktur sosial dan praktek dimana laki-laki mendominasi, menindas dan mengekploitasi perempuan (Walby 1990, 20). Walby menjelaskan patriarki sebagai sistem untuk menolak determinasi biologis yang mengatakan secara alamiah laki-laki dan perempuan memang berbeda karena perbedaan biologis sehinga keduanya pun punya peran berbeda.
Merujuk pada pandangan Millet patriarki tidak lahir secara alamiah, melainkan hasil dari konstruksi sosial yang dilembagakan dan melahirkan ideologi maskulinitas dimana laki-laki mendominasi sedangkan perempuan tersubordinasi. Pelembagaan melalui berbagai institusi seperti lembaga ilmiah, gereja, keluarga, dimana masing-masing memberikan pembenaran (justifikasi) dan memaksakan terjadinya subordinasi perempuan oleh laki-laki (Millett 1997, 35). Manifestasi patriarki yang terefleksi adanya domonasi laki-laki atas perempuan baik dalam keluarga maupun kehidupan masyarakat secara umum terlembaga di hampir semua masyarakat dunia. Implikasinya adalah laki-laki mengambil semua sumber-sumber kekuasaan yang penting di masyarakat, bahkan perempuan dicabut aksesnya atas sumber-sumber kekuasaan tersebut. Meskipun demikian, patriarki sendiri tidak mampu sepenuhnya menjadikan perempuan tidak berkuasa, tercabut hak-haknya, tidak memiliki pengaruh ataupun sumber daya (Lerner 1987, 239).

Di Indonesia praktek patriarki sendiri bukan hal baru terutama karena masyarakat yang bersifat patriakhat yang kemudian diperkuat oleh tradisi agama yang parsial dalam menafsirkan peran dan posisi perempuan. Namun semakin menguatnya gerakan oleh penggiat perempuan yang memperjuangkan kesetaraan gender, maka posisi perempuan di Indonesia sesungguhnya sudah lebih baik. Tidak sedikit kaum perempuan yang dapat ambil bagian dalam peran-peran penting di sektor publik. Terkait dengan Pilkades di Kabupaten Demak juga menunjukan bahwa meskipun perempuan yang maju sebagai calon sebatas calon pendamping atau calon pura-pura yang tidak melakukan upaya apapun, termasuk kampanye untuk dirinya, namun hasilnya menunjukan bahwa di beberapa desa kontestan perempuan tersebut memperoleh dukungan yang signifikan misalnya di Bonangrejo Kecamatan Bonang. 
Calon Kades Bonangrejo Umroh Setianingsih mendapatkan 741 suara sedangkan suaminya Asnawi mendapatkan 1.694 suara. Perbedaan yang tidak terlalu jauh dengan suami (laki-laki) juga terjadi di desa Karangmlati Kecamatan Demak, Calon Kades Nur Chasanah mendapatkan suara 910 sedangkan suaminya Agus Mulyono Kartono mendapatkan suara 1,222 suara. Hal serupa juga terjadi di Desa Tlogosih Kecamatan Kebon Agung, Calon Kades Yeni Ristiani mendapatkan 583 suara sementara suaminya Ustad mendapatkan 1.137 suara.

Dari data tersebut menunjukan bahwa meskipun istri (perempuan) hanya sebagai calon pendamping yang tidak melakukan kampanye namun dukungan yang diperoleh cukup signifikan. Para suami yang pada awalnya memutuskan memilih istri sebagai calon pendamping bahkan cukup kaget ketika proses pemungutan suara dimulai ternyata perolehan suara sang istri cukup tinggi, seperti yang disampaikan oleh Ustad Kepala Desa Tlogosih yang merupakan petahanan dan maju untuk menjabat yang ke tiga kali:

"Saya cukup kaget ketika pemungutan suara berlangsung karena di awal-awal perhitungan suara yang muncul adalah nama istri saya. Saya terus terang merasa cemas kalau-kalau istri saya yang memenangkan pemilihan karena tidak saya perkirakan sebelumnya kalau dukungan terhadap istri ternyata cukup besar. Walaupun sesungguhnya kalau istri saya menang artinya kemenangan masih ada pada keluarga kami, tapi tetap ada perasaan malu kalau saya sampai kalah". (Ustad, Kepala Desa Tlogosih)

Pernyataan Ustad sebenarnya mempertegas pendapat-pendapat sebelumnya bahwa keputusan memilih istri sebagai pesaing dalam pencalonan Pilkades di samping upaya pemenuhan persyaratan administratif agar Pilkades tidak tertunda, juga karena alasan superioritas dan supremasi laki-laki yang tidak memandang penting posisi perempuan. Pada konteks ini praktek subordinasi dapat dimaknai sebagai "sesuatu yang dinilai kurang penting dibandingkan dengan lainya" atau kurang memiliki kekuasaan atau kewenangan dibandingkan dengan lainya dalam suatu kelompok atau organisasi. Patriarki dan subordinasi merupakan dua hal yang tidak terpisahkan karena karena patriarki maka perempuan menjadi tersubordinasi dengan berbagai bentuknya seperti diskriminasi, pengabaian, penindasan, pengendalian, penghinaan, eksploitasi dan kekerasan.

Kondisi tersebut juga ditunjukkan dalam penelitian Ahmad Faris (2015) terkait pola kepemimpinan kultural di Demak yang direpresentasikan melalui kiprah dan pola kepemimpinan kiai (pemuka agama). Hasil riset menunjukkan bahwa pola kepemimpinan yang lazim ditemukan di Demak adalah bentuk kepemimpinan yang mendominasikan peran laki-laki, pada konteks ini terepresentasi melalui peran dominasi laki-laki dalam pengelolaan dan pengembangan institusi pendidikan kultural. Pada studi kasus tersebut nampak jelas bahwa laki-laki memegang seluruh kendali dalam struktur organisasi yang berujung pada sistem pengelolaan dan pengembangan pondok pesantren yang dikelola. Studi kasus tersebut menjadi relevan dalam lingkungan sosio-kultural Demak, mengingat komposisi masyarakat Demak yang didominasi oleh kultur islam. Hal tersebut dapat ditinjau melalui eksistensi Demak sebagai salah satu kota religi dengan beragam destinasi wisata religi pun sebagai destinasi pendidikan religi baik kultural maupun modern. Oleh karena itu, kehidupan sosio-kultural masyarakat Demak banyak dipengaruhi oleh nilai dan norma ajaran islam. Termasuk pada konteks pola kepemimpinan yang menempatkan laki-laki dalam posisi yang mendominasi perempuan baik dalam penentuan kebijakan hingga pada praktek pengambilan keputusan. 


\section{Kompetisi Semu dalam Pilkades}

Desa merupakan entitas pemerintahan yang strategis karena langsung berhubungan dengan masyarakat, bahkan sejak masa kekuasaan kolonial Belanda desa telah menjadi basis penyelenggaraan pelayanan publik. Oleh karena itu pemerintah kolonial secara tegas memberikan ruang kepada masyarakat dan desa untuk menyelenggarakan pemerintahannya sendiri yang diwujudkan dalam bentuk pengakuan hak-hak budaya desa, sistem pemilihan desa, desentralisasi pemerintahan, bahkan sampai parlemen desa. Pola pemilihan pemimpin desa oleh pemerintah kolonial Belanda bahkan diserahkan sepenuhnya kepada masyarakat desa. Pada masa lalu seorang kepala desa dituntut mengedepankan aspek kultural dalam kepemimpinannya.

Kebudayaan sendiri dapat diartikan sebagai keseluruhan gagasan, tindakan, dan hasil karya dalam rangka kehidupan masyarakat yang dijadikan milik dari manusia dengan belajar (Koentjaraningrat 2009). Oleh karena itu wajar apabila kepemimpinan desa sangatlah beragam sesuai dengan kebudayaan daerah yang mempengaruhinya. Pada masyarakat Jawa misalnya ditanamkan nilai-nilai kepemiminan bahwa seorang pemimpin tidak boleh sewenang-wenang (ojo dumeh), harus bisa melindungi rakyat (ngayomi) dan harus bisa menciptakan rasa nyaman (ngayemi). Kemampuan seorang pemimpin mengadopsi niai-nilai tersebut bukanlah hasil yang didapatkan secara instan, akan tetapi hasil dari proses sosialisasi yang panjang. Proses tersebutlah yang akan mengkonstruksi budaya politik sebagai bentuk responsif atas nilai maupun norma kultural yang berkembang di suatu daerah. Begitu pula yang terjadi dalam proses kepemimpinan kultural di Demak, dimana aktivitas keseharian masyarakat banyak dipengaruhi oleh nilai dan norma ajaran islam di samping nilai dan norma Jawa mengingat masyarakat Demak merupakan bagian dari suku bangsa Jawa. Pada konteks ini, suku bangsa Jawa merupakan salah satu suku bangsa yang mengimplementasikan sistem patriarki yang melandasi setiap kebijakan dan praktek pengambilan keputusan. Maka pola yang nampak pada keseharian masyarakat termasuk dalam pola kepemimpinannya merupakan praktek dominasi laki-laki.

Dalam konteks masa kini, kepemimpinan kepala desa memang banyak mengalami pergeseran dimana seorang kepala desa bukan hanya harus memiliki kemampuan adaptif terhadap budaya lokal (cultural leadership), akan tetapi juga dituntut memiliki kemampuan administratif (administrative leadership). Kenyataan ini tidak lepas dari intervensi regulasi yang menempatkan posisi atau kedudukan desa di samping sebagai entitas yang memiliki otonomi, tetapi di sisi lain juga merupakan bagian dari pemerintahan nasional sehingga kepala desa sesungguhnya juga pemimpin pemerintahan. Dalam pendekatan tata kelola pemerintahan yang baik (good governance) maka seorang pemimpin pemerintahan dalam level apapun harus mampu memanfaatkan manajemen yang dijalankan dengan kompeten untuk mengurus sumber daya dalam rangka memenuhi kepentingan semua pihak (stakeholder) sesuai dengan prinsip-prinsip keadilan, kejujuran, persamaan, efisisiensi, transparansi, dan akuntabilitas (Aminah 2014, 266-7). Kualitas kepemimpinan desa ini tentu tidak dapat dilepaskan dari mekanisme dalam menemukan atau melahirkan pemimpin yaitu pemilihan kepala desa.

Pilkades sebagai mekanisme dalam proses memilih pemimpin merupakan peristiwa politik di tingkat desa yang paling menarik karena munculnya berbagai peristiwa yang menyertainya, seperti konflik diantara calon dan pemilih, munculnya protes sebagai respon terhadap ketidakpuasan hasil pemungutan suara, politik uang (money politics), hingga pada pemungutan suara yang diulang karena kemenangan kotak kosong. Fakta inilah yang menyebabkan Pilkades 
selalu menarik untuk dikaji. Terkait dengan larangan calon tunggal untuk melawan kotak kosong realitanya telah memunculkan fenomena baru sebagai respon atas kondisi tersebut yakni munculnya pasangan suami istri sebagai kontestan di berbagai kabupaten di Jawa Tengah, termasuk di Kabupaten Demak. Fenomena ini sangat menarik untuk dikaji karena terkait dengan kualitas proses demokrasi desa dimana Pilkades merupakan pilar utamanya.

Pilkades juga merupakan upaya untuk memilih pemimpin secara demokratis. Menurut Philip $(2011,22)$ pemilihan merupakan sarana membangun demokrasi yang di dalamnya harus memuat prinsip-prinsip antara lain kebebasan individu, hak asasi manusia, tidak diskriminatif atas dasar agama, etnis atau gender, dan adanya kesempatan untuk berpartisipasi dan elemen kompetisi. Lebih jauh Philip menyatakan bahwa ketiadaan dari salah satu komponen tersebut akan berpeluang melahirkan pemerintahan yang buruk (bad government). Sementara menurut Huntington, demokrasi dimaknai sebagai keputusan kolektif yang adil, jujur dan berkala, dimana dalam sistem tersebut para calon secara bebas bersaing untuk memperoleh suara serta hampir semua penduduk dewasa berhak memberikan suara (Huntington 2001, 5) Sedangkan Dahl menjelaskan bahwa untuk menilai demokrasi dapat dinilai dari bekerjanya tiga nilai penting yaitu kontestasi (kompetisi), liberalisasi dan partisipasi (Dahl 1971, 6-7). Dalam pengertian ini maka proses pemilihan menjadi sangat penting dimana setiap individu dijamin kebebasanya baik untuk memilih maupun untuk berkompetisi dalam memenangkan jabatan.

Jika dilihat dari beberapa pengertian demokrasi tersebut maka munculnya pasangan suami istri dalam kontestasi Pilkades sangat berpotensi menurunkan kualitas proses demokrasi desa. Hal tersebut dikarenakan kontestasi yang terjadi dalam Pilkades sesungguhnya merupakan kompetisi semu dimana para pemilih sesungguhnya tidak memiliki pilihan alternatif karena seperti apapun hasil perolehan suaranya maka kemenangan masih berada pada lingkaran kedua kontestan tersebut (suami atau istrinya). Sementara pada sisi yang lain seorang istri (perempuan) sebagai calon tidak memiliki kebebasan untuk berkampanye dalam menggalang dukungan suara bagi dirinya karena memang dilarang oleh suaminya. Fakta ini memperkuat kondisi terjadinya praktek subordinasi perempuan akibat supremasi laki-laki. Akan berbeda misalnya meskipun kontestasnya merupakan pasangan suami istri, akan tetapi keduanya memiliki peluang dan kesempatan yang sama untuk menggalang dukungan suara.

Kabupaten Demak memang daerah yang banyak menghasilkan komoditas padi disetiap musim panennya, oleh karena itu posisi kepala desa menjadi salah satu jabatan yang memiliki prestige sosial tinggi mengingat besarnya tanah 'bengkok' yang dapat dikelola oleh kepala desa selama menjabat. Di beberapa desa yang tanah bengkoknya bisa panen hingga tiga kali dalam setahun, seorang calon kepala desa tidak segan menggelontorkan dana hingga ratusan bahkan milyaran untuk pencalonanya. Maka bukan hal mustahil jika pada akhirnya orang yang berani maju dalam pencalonan kepala desa adalah mereka-mereka yang bukan hanya memiliki modal sosial dan modal politik, tetapi juga harus memiliki modal ekonomi. Sulitnya untuk menghilangkan politik uang dalam sebuah proses demokrasi telah ditulis oleh Anthony Downs bahwa yang menyatakan bahwa dalam ruang politik warga negara akan bertindak secara rasional. Orang pun akan memberikan suaranya pada partai, atau calon yang bisa memberikan manfaat lebih dibandingkan yang lainnya (Downs 2001). Rasionalitas pemilih dalam Pilkades dapat diartikan sebagai keinginan untuk mendapatkan uang dari calon sebagai imbalan 
atas dukungan suara yang diberikan sebagai hal yang logis. Hal tersebut dikarenakan rasionalitas yang demikian bisa merusak proses demokrasi yang jujur, adil dan bersih, maka pemerintah pun melarang praktek politik uang dalam proses pemilihan apapun, termasuk Pilkades. Namun pada prakteknya menghilangkan politik uang menjadi persoalan yang tidak mudah.

Larangan calon tunggal melawan kotak kosong yang melahirkan kontestan pasangan suami istri berdampak pada rusaknya sendisendi demokrasi karena terjadinya kompetisi semu serta politik uang yang semakin terbuka. Dalam rangka memperbaiki realitas ini maka pemerintah harus memperbaiki regulasi yang mempertegas persyaratan pencalonan, dimana dalam pencalonan Pilkades yang sedikitnya diikuti oleh dua calon dan sebanyak-banyaknya lima calon, maka jika kalau diikuti oleh dua calon keduanya tidak boleh memiliki hubungan sebagai keluarga inti seperti, suami, istri dan anak. Pada umumnya, masyarakat juga memiliki persepsi yang sama yakni suasana demokrasi yang tidak kondusif karena keterlibatan keluarga inti dalam proses pencalonan. Kondisi tersebut dikhawatirkan justru akan melanggengkan konsep politik dinasti dimana yang menjadi pemimpin hanya berasal dari keluarga besar tertentu saja secara berturut turut.

\section{Simpulan}

Terdapat beberapa kesimpulan dalam analisis fenomena pasangan suami istri sebagai kontestan dalam Pilkades Kabupaten Demak tahun 2016. Pertama yakni terjadinya praktek subordinasi perempuan karena keputusan menetapkan istri sebagai calon pendamping merupakan bentuk kepatuhan istri atas kemauan dan perintah suami. Pada konteks ini keputusan untuk menempatkan istri sebagai calon kontestan Pilkades guna mengindari kotak kosong merupakan alternatif calon kades (laki-laki) untuk meminimalisas risiko dan ongkos politik dalam pelaksanaan Pilkades. Mengingat munculnya peraturan baru yang melarang adanya calon melawan kotak kosong. Maka penempatan istri sebagai calon rival dalam Pilkades merupakan situasi dan kondisi yang telah diorientasikan untuk mendatangkan keuntungan lebih bagi suami yang nota benenya menjadi rival dalam Pilkades. Kondisi ini adalah bentuk nyata dari pengabaian terhadap hak-hak perempuan (istri). Kemudian keyakinan para suami (laki-laki) ketika yang menjadi pesaing adalah istri (perempuan) maka peluang keterpilihan menjadi semakin besar karena masyarakat Demak diyakini lebih senang memilih laki-laki (yang diidentikan sebagai ayam jantan atau petarung) dibandingkan dengan perempuan. Terlebih para istri (perempuan) sebagai calon dalam Pilkades juga tidak diperbolehkan melakukan kampanye untuk memperoleh dukungan. Kondisi tersebut banyak dipengaruhi oleh pola kepemimpinan kultural Demak dengan pola akulturasi nilai dan norma yang berkembang dalam etnis Jawa dan Islam.

Simpulan kedua terkait dengan dampak yang timbul dari fenomena kontestasi pasangan suami istri dalam Pilkades karena dapat merusak sendisendi demokrasi desa. Pernyataan tersebut merujuk pada hilangnya prinsip kompetisi dalam pelaksanaan Pilkades. Meskipun terdapat minimal dua calon dan tidak melawan kotak kosong, namun jika rival calon yang lain adalah keluarga inti (pada konteks kajian ini adalah istri) maka kompetisi yang akan muncul berpotensi mengarah pada kompetisi yang telah diorientasikan untuk memenangkan salah satu calon (suami). Terlebih ditemukan beberapa kasus dimana istri tidak diperbolehkan melakukan kampanye bahkan istri justru mengkampanyekan suaminya untuk bisa dipilih dalam pelaksanaan Pilkades. Jikalaupun justru istri yang akan memenangkan Pilkades, maka kondisi tersebut berpotensi mengarah pada pelanggengan konsep politik dinasti, mengingat suami masih tetap akan campur tangan dalam masa kepemimpinannya[] 


\section{Daftar Pustaka}

Aminah, Siti. 2014. Kuasa Negara pada Ranah Politik Lokal. Jakarta: Prenada Media Group.

Bhasin, K. 2006. What is Patriarchy? New Delhi: Women Unimited.

Dahl, Robert Alan. 1971. Polyarchy: Participation and Opposition. New Haven, USA: Yale University Press. https://books.google.co.id/books?id=LRG7ngEACAAJ.

Downs, Anthony. 2001. An Economic Theory of Democracy. Boston: Addison-Wesley.

Faris, Ahmad. 2015. "Kepemimpinan Kiai dalam Mengembangkan Pendidikan Pesantren." 'Anil Islam: Jurnal Kebudayaan dan Ilmu Keislaman 8(1): 123-44. http://jurnal.instika.ac.id/index.php/ Anillslam/article/view/17.

Huntington, Samuel P. 2001. Gelombang Demokratisasi Ketiga. Jakarta: Pustaka Utama Grafiti.

Koentjaraningrat. 2009. Pengantar Antropologi Pokok-pokok Etnografi. Jakarta: Rineka Cipta.

Lerner, Gerda. 1987. The Creation of Patriarchy. New York: Oxford University Press.

Millett, Kate. 1997. Sexual Politics. London: Virago.

Philip, G. 2011. Democracy and Democratisation. London: University of London.

Walby, Sylvia. 1990. Theorizing Patriarchy. Oxford, UK \& Cambridge, USA: Blackwell Publisher Ltd. 